\title{
Perencanaan Pembangunan Infrastruktur Perdesaan: Kajian Pustaka Terstruktur
}

\section{Rural Infrastructure Development Planning: Structured Literature Review}

\author{
Anisa Ana Fitrianti ${ }^{1 *}$, Ach. Apriyanto Romadhan ${ }^{1} \&$ Salahudin $^{1}$ \\ ${ }^{1}$ Program Studi Ilmu Pemerintahan, Fakultas Ilmu Sosial dan Ilmu Politik, Universitas Muhammadiyah \\ Malang, Gedung Kuliah Bersama Lantai 6, Kampus 3 Tlogomas 65144, Indonesia; \\ *Penulis korespondensi. e-mail: anafanisa6@gmail.com \\ (Diterima: 26 Juli 2021; Disetujui: 14 Oktober 2021)
}

\begin{abstract}
This study aims to provide an understanding of village development planning in the infrastructure sector using the literature review method, which is to review and re-read the main ideas on the same topic and then add arguments and the author's views or opinions on the topic to be raised. On the other hand, by using a review system like this, authors can also see the shortcomings of previous researchers so that they can formulate and improve regularly. This research reveals that in village development planning currently, it is necessary to have an effective plan and of course produce good planning. Therefore, this study aims to provide a critical review of several articles published on Scopus and categorize themes or concepts related to the study of village development planning. Through descriptive analysis, this study uses a literature review method using VOSviewer software and produces 267 articles indexed by Scopus. Furthermore, this research deals with dominant themes such as rural area, land, rural development. The result and discussion are related to the theme of village development planning in the infrastructure sector, showing that there are 145 concepts in the study of village development planning.
\end{abstract}

Keywords : infrastructure, rural area, theme cluster, writer cluster

\begin{abstract}
ABSTRAK
Kajian ini bertujuan untuk memberikan pemahaman terkait perencanaan pembangunan infrastruktur perdesaan dengan menggunakan metode literature review yaitu mengkaji serta membaca kembali pokok-pokok pikiran tentang topik yang sama dan kemudian menambahkan argumen serta pandangan atau pendapat penulis mengenai topik yang akan diangkat. Di sisi lain, dengan menggunakan sistem reviu seperti ini, penulis dapat melihat kekurangan dari penelitianpenelitian sebelumnya, sehingga dapat melakukan perumusan dan perbaikan kembali secara teratur. Penelitian ini mengungkapkan bahwa dalam perencanaan pembangunan perdesaan pada saat ini perlu adanya sebuah perencanaan yang efektif dan tentunya menghasilkan perencanaan yang baik. Oleh karena itu, kajian ini bertujuan untuk memberikan critical review terhadap beberapa artikel yang terpublikasi pada Scopus dan mengkategorikan tema atau konsep yang berkaitan dengan kajian perencanaan pembangunan desa. Melalui analisis deskriptif, kajian ini menggunakan metode literature review dengan menggunakan perangkat lunak VOSviewer, dan menghasilkan 267 artikel yang terindeks Scopus. Kajian ini mengungkapkan beberapa temuan melalui hasil dan pembahasan di setiap jurnal. Hasil dan pembahasan berkaitan dengan tema rural infrastructure development
\end{abstract}


planning menunjukkan bahwa terdapat 145 konsep dalam kajian perencanaan pembangunan desa. Lebih lanjut, kajian ini berkaitan dengan tema yang dominan seperti rural area, land, rural development.

Kata kunci : infrastruktur, kluster penulis, kluster tema, perdesaan

\section{PENDAHULUAN}

Dalam sebuah penelitian, ketika ingin mengetahui tentang suatu hal maka perlu adanya sebuah data yang dapat digunakan untuk menganalisis suatu hal tersebut. Analisis yang dilakukan terhadap variabel-variabel yang menjadi pisau analisis berupa data atau penemuan baru dari suatu hal yang akan diteliti berguna untuk menggali sumber data yang sekiranya tidak dapat dilakukan secara langsung. Maka hal ini dapat menggunakan sistem review paper dalam menganalisisnya. Melalui proses review paper dapat meningkatkan pemahaman kita pada saat menganalisis data, serta akan membangun argumentasi yang baik untuk menyatakan pendapat mengenai judul yang kita angkat. Di sisi lain, dengan adanya review paper juga berguna untuk melihat bagaimana pendapat atau perspektif dari penulis lain mengenai permasalahan yang diangkat, sehingga dapat memberikan acuan kepada penulis lain untuk mengembangkan pendapatnya.

Dalam hal melakukan reviu jurnal, ada beberapa hal yang perlu kita lakukan, di antaranya yaitu : (1) Menemukan jurnal yang sesuai dengan topik penelitian yang diangkat (2) Membaca keseluruhan dari isi jurnal tersebut, dan (3) Mencoba untuk menuliskan kembali dengan bahasa sendiri pengertian atau pembahasan dari jurnal atau paper tersebut. Sehingga dari penjelasan tersebut dapat ditarik kesimpulan bahwa reviu jurnal merupakan tulisan yang berisi tentang beberapa ringkasan kajian ilmiah yang berfokus pada topik-topik tertentu saja. Selain itu, reviu jurnal juga dapat dikatakan atau dianggap sebagai ringkasan dan evaluasi dari orang lain. Selanjutnya penelitian ini bertujuan untuk menjelaskan informasi apa saja yang digunakan dalam perencanaan pembangunan desa dalam bidang infrastruktur.
Selain itu kajian ini bertujuan untuk memberikan critical review terhadap beberapa artikel yang terpublikasi pada Scopus dan mengkategorikan tema atau konsep yang berkaitan dengan kajian perencanaan pembangunan desa. Melalui analisis deskriptif, penelitian ini menggunakan metode review paper dengan menggunakan perangkat lunak VOSviewer, dan menghasilkan 267 artikel yang terindeks Scopus. Perbedaan artikel ini dari artikel-artikel sebelumnya adalah artikel ini dalam analisisnya menggunakan analisis deskriptif dengan studi literature review. Biasanya studi pada artikel-artikel sebelumnya dipelajari hanya dengan cara empiris dengan mengambil data di lapangan dan menggunakan data kualitatif atau data kuantitatif sebagai metode penelitian. Dengan adanya penulisan reviu jurnal ini bertujuan untuk memberikan pemahaman yang lebih baik tentang topik tertentu, sehingga akan memberikan kemudahan individu dalam memahami beberapa topik tanpa membaca seluruh buku atau berbagai jenis dokumen publik. Dengan demikian dapat melihat analisis peneliti mengenai Perencanaan Pembangunan Infrastruktur Perdesaan.

Perencanaan pembangunan desa merupakan suatu hal yang tidak semata-mata karena adanya sebuah kesempatan melainkan hal ini merupakan hasil dari penentuanpenentuan pilihan dari beberapa proses kegiatan dengan adanya perencanaan yang baik. Untuk menyelenggarakan pembangunan tersebut maka Pemerintah Desa perlu menyusun perencanaan desa yang tentunya melibatkan seluruh komponen yang terkait seperti masyarakat desa dan stakeholder. Dengan demikian proses perencanaan yang baik akan menghasilkan hasil yang baik dari pelaksanaan program. Proses merencanakan, melaksanakan, dan mengevaluasi ini merupakan wujud nyata dari 
kewenangan mengatur dan mengurus pembangunan desa yang terhitung dalam skala lokal desa. Kemudian dalam hal pembangunan infrastruktur desa masih banyak ditemukan beberapa perencanaan yang kurang efektif pada saat ini. Hal tersebut diakibatkan oleh penyusunan rencana pembangunan yang kurang baik karena minimnya dukungan sejumlah data serta informasi yang memadai. Realita yang ada pada dasarnya perencanaan merupakan sebuah solusi untuk memecahkan permasalahan yang ada. Namun tidak semua hal itu dapat berjalan sedemikian baik karena beberapa faktor pendukung. Maka dari itu, pembangunan berbasis partisipasi masyarakat kini menjadi solusi untuk kebijakan yang telah ditetapkan untuk perencanaan pembangunan. Melalui partisipasi masyarakat dapat menghasilkan keputusan perencanaan dan desain berdasarkan kebutuhan, prioritas, dan keterjangkauan komunitas yang sering menghasilkan desain, rencana, serta program yang lebih baik dan realistis (Wikantiyoso et al., 2021). Pembangunan desa juga dipengaruhi oleh adanya perpindahan penduduk sebagaimana dalam jurnal yang berjudul "Development Models Matter To The Mutual Growth Of Ecosystem Services And Household Incomes In Developing Rural Neighborhoods" (K. Zhang et al., 2020) menjelaskan bahwa perpindahan penduduk yang diakibatkan urbanisasi menyebabkan banyak masyarakat perdesaan yang mengalami peningkatan dramatis pada proporsi lahan konstruksi sehingga hal ini menyebabkan berkurangnya layanan ekosistem. Bagi masyarakat perdesaan, mempertahankan layanan ekosistem dan meningkatkan pendapatan rumah tangga merupakan hal yang sangat penting karena berhubungan dengan pembangunan perdesaan. Namun pada kenyataannya layanan ekosistem di perkotaan sangat tidak mendukung adanya pembangunan desa. Hal tersebut dikarenakan peningkatan populasi dari tahun ke tahun membuat padatnya lahan permukiman di perkotaan dan menurunnya populasi di desa. Dengan begitu pembangunan desa dalam bidang infrastruktur akan terganggu dan tidak berjalan secara efektif.

Dengan melihat permasalahan tersebut maka dalam perencanaan pembangunan khususnya pada wilayah perdesaan perlu adanya perumusan kebutuhan serta strategi apa saja dalam menyelesaikan permasalahan yang ada di dalam masyarakat. Selain itu pemenuhan kebutuhan lain dengan menyesuaikan sumber daya desa dan otonomi desa serta alokasi dana desa yang diberikan oleh pemerintah kepada desa-desa merupakan hal yang sangat penting. Beberapa kajian tentang perencanaan pembangunan desa dalam bidang infrastruktur telah banyak dilakukan oleh peneliti dengan tujuan untuk mengetahui sejauh mana tata kelola yang baik tentang perencanaan pembangunan desa terutama dalam bidang infrastruktur. Pentingnya penelitian dalam artikel ini adalah dapat digunakan sebagai sumber informasi dan beberapa data untuk penelitian selanjutnya. Makna penting dari studi ini adalah ditemukannya konsep studi perencanaan pembangunan infrastruktur perdesaan. Dengan demikian kajian ini dapat membantu dalam kerangka konseptual dalam penelitian selanjutnya. Adapun keterbatasan penelitian ini selain minimnya sumber jurnal adalah hanya bersumber pada database scopus dan minimnya variabel yang diteliti untuk memperoleh informasi dari beberapa jurnal yang menyebabkan tidak memiliki data pembanding. Penelitian berikutnya perlu menggunakan artikel tidak hanya dari database scopus namun menggunakan database lain seperti google scholar dan lain-lain.

\section{Tinjauan Pustaka}

Penerapan desain kualitatif melalui analisis dokumen rencana dan kebijakan serta wawancara di desa dengan administrasi kota dilakukan untuk menganalisis sejauh mana dan bagaimana rencana desa dan kebijakan perdesaan serta kesehatan kota yang telah dikoordinasikan pada tiga lokasi kasus di daerah perdesaan Denmark. Secara teoritis hasil dari artikel ini dibangun berdasarkan koordinasi kepada kelembagaan yang telah dilakukan 
antara perencanaan yang dipimpin oleh masyarakat dan perencanaan hukum. Hasil dari penelitian ini adalah, pertama menunjukkan bahwa meskipun dari kalangan masyarakat diharapkan pembangunan desa untuk perencanaan pembangunan kesehatan dapat mempengaruhi keberhasilan dari pelaksanaan intervensi kesehatan meskipun di dalam pembangunan tersebut ada tindakan inovatif terhadap integrasi pada tingkat desa. Kedua, isu-isu seperti apa yang dapat dikatakan sebagai isu yang dapat kita sebut sebagai "Perencanaan Jinak", tentang kesulitan dalam pendekatan kepada keragaman desa, dan hambatan serta strategi yang diidentifikasi untuk mengatasi pembangunan desa (Thuesen \& Andersen, 2021).

Perencanaan perdesaan di Indonesia pada saat ini mengalami perubahan yang signifikan dalam satu dekade terakhir. Pembangunan berbasis partisipasi masyarakat kini menjadi kebijakan yang telah ditetapkan untuk perencanaan pembangunan pertanian. Melalui partisipasi masyarakat dapat menghasilkan keputusan perencanaan dan desain berdasarkan kebutuhan, prioritas, dan keterjangkauan komunitas yang sering menghasilkan desain, rencana, serta program yang lebih baik dan realistis. Dalam pengembangan wisata kampong, pelaksanaan partisipasi masyarakat dapat mengurangi biaya, meningkatkan penggunaan sumber daya lokal, serta dapat memberdayakan masyarakat secara sosial. Kampong Grangsil merupakan dusun petani bunga yang karakteristik masyarakatnya pekerja keras dan berpikiran terbuka. Tingginya tingkat partisipasi masyarakat dan Program Pengembangan Mitra Desa yang tertata menghasilkan Kampong Grangsil menjadi desa yang berkelanjutan. Program Pengembangan Mitra Desa ini dilakukan dengan memperkuat sumber daya lokal kampong tersebut. Sepanjang pada program pendampingan dan pengembangan ini tim peneliti berperan sebagai mediator dan fasilitator untuk pengembangan Grangsil menjadi destinasi pariwisata yang lebih ramah lingkungan. Peran dan keterlibatan peneliti sebagai mediator dalam proses pembangunan partisipatif dapat berguna untuk meningkatkan kemampuan masyarakat untuk menata dan membangun desa berkelanjutan (Wikantiyoso et al., 2021).

Pemerintah Tiongkok telah memilih pembangunan smart villages sebagai strategi untuk mewujudkan pembangunan kawasan perdesaan yang berkelanjutan. Dalam artikel ini, didefinisikan bahwa desa cerdas sebagai model pembangunan perdesaan yang sepenuhnya menggunakan pemanfaatan teknologi informasi dan komunikasi (TIK) sebagai solusi untuk membangun desa yang lebih berkelanjutan. Selain itu pemanfaatan teknologi informasi dan komunikasi (TIK) dapat digunakan untuk mempromosikan pembangunan desa secara berkelanjutan dengan tujuan memperjelas bagaimana karakteristik dan kebutuhan di dalam proses pembangunan desa. Hasil penelitian menunjukkan bahwa pembangunan dan pengembangan desa pintar dan berkelanjutan di daerah perdesaan yang masih tertinggal di Tiongkok merupakan pilihan yang tepat sesuai dengan situasi pada saat ini di China. Peran pemerintah Tiongkok dalam mempromosikan pembangunan desa pintar dilakukan dengan cara mempromosikan subsistem yang strategis pada sistem desa pintar. Promosi yang dilakukan oleh pemerintah Tiongkok ini bertujuan untuk meningkatkan pembangunan kawasan perdesaan yang cerdas. Melalui rencana keseluruhan terpadu dan kebijakan pendukung terkait model konstruksi desa pintar top-down yang saat ini mulai diadopsi oleh China, model konstruksi desa ini mengacu pada sistem politik dan ekonomi China yang cenderung pada sentralisasi kekuasaan dan dominasi ekonomi publik (X. Zhang et al., 2020).

Studi kasus Suwon ini menunjukkan bahwa pemerintah Korea telah menyiapkan proyek untuk penyebaran kompleks perumahan yang ramah lingkungan dengan berusaha memperkenalkan standar konstruksi ramah lingkungan untuk perwujudan kompleks perumahan tersebut. Pemerintah pusat sangat berupaya aktif dalam membangun sistem untuk mempromosikan bagaimana teknologi 
konstruksi yang ramah lingkungan dengan mendorong orang-orang untuk menggunakan metode dan produk konstruksi yang ramah lingkungan. Tujuan dari penelitian ini adalah : (1) untuk penetapan rencana penggunaan lahan yang digunakan sebagai eko-desa di Suwon, (2) untuk menentukan rencana ruang eksternal yang mencakup aspek lingkungan di dalamnya, dan (3) untuk menetapkan desain alternatif dengan proses pengambilan keputusan secara multi-kriteria (Moon et al., 2020).

Nilai daerah perdesaan yang beragam telah banyak disorot secara bertahap melalui promosi pembangunan kawasan perdesaan yang berkelanjutan. Dengan panduan teoritis multifungsi perdesaan adalah kunci untuk mewujudkan revitalisasi perdesaan. Penelitian ini mendefinisikan konsep perdesaan yang multifungsi dari perspektif tuntutan penduduk yang kemudian dibagi menjadi lima fungsi utama yaitu termasuk pada produksi pertanian perdesaan, produksi non-agricultural, kehidupan, lingkungan ekologis, dan jaminan sosial. Penulis menganalisis karakteristik dari 160 desa Jingjiang di Provinsi Jiangsu dengan kombinasi yang fungsional melalui identifikasi untuk memilih jalur pembangunan perdesaan yang ditargetkan untuk pengembangan multifungsi perdesaan yang seimbang. Hasil dari penelitian ini menunjukkan pengembangan berbagai fungsi perdesaan di Jingjiang tidak merata, (2) desa-desa yang memiliki tingkat produksi non-agricultural sebagian besar didistribusikan kepada taman industri atau di sekitar kota. Padahal masih banyak jaminan sosial, terutama di perdesaan yang didominasi oleh produksi nonagricultural, (3) pembangunan yang seimbang kedepannya harus lebih merata lagi sesuai dengan fungsi pembangunan perdesaan untuk mencapai multifungsi. Selanjutnya adalah panduan ilmiah untuk pertumbuhan fungsional desa-desa di Jingjiang dengan dukungan teoritis yang bertujuan untuk evaluasi skala mikro multifungsi perdesaan serta penerapannya. (He et al., 2020)

Banyaknya penduduk Gullies yang pindah ke Tableland menyebabkan hilangnya lereng Desa Gully di daerah dataran tinggi Gully. Hal tersebut dikarenakan lokasi desa, kondisi berkembang, dan daya dukung ekologis desa-desa di sekitarnya sangat berpengaruh pada arah pembangunan desa-desa dan perencanaan sistem daerah ini. Melalui metode analisis komparatif dari berbagai metode analisis untuk menentukan kapasitas angkut ekologis, artikel ini mengambil metode analisis faktor pembatas yang digunakan sebagai metode utama untuk meningkatkan kondisi lokal. Melalui analisis daya dukung ekologis maksimum pada saat ini kita dapat menentukan desa mana yang harus diintegrasikan dengan orang lain dengan tujuan untuk meningkatkan lingkungan pemukiman bagi penduduk desa. Pada saat ini, desa dinilai dapat dijadikan sebagai lingkungan pemukiman masa depan yang dapat dianalisis dan diprediksi lebih lanjut untuk kedepannya di sisi lain juga dapat diadopsi sebagai panduan penting untuk relokasi dan kombinasi desa setempat (T.Zhang et al., 2020).

Dalam konteks percepatan urbanisasi, banyak masyarakat perdesaan yang mengalami peningkatan dramatis pada proporsi lahan konstruksi sehingga hal ini menyebabkan berkurangnya layanan ekosistem. Bagi masyarakat perdesaan mempertahankan layanan ekosistem dan meningkatkan pendapatan rumah tangga merupakan hal yang sangat penting karena berhubungan dengan pembangunan perdesaan. Untuk mengetahui hubungan antara pendapatan rumah tangga dengan faktor-faktor yang mempengaruhi layanan ekosistem maka penilaian layanan ekosistem dilakukan pada 30 desa di Provinsi Shandong yang berkembang pesat di Cina Timur. Dalam survey ini menganalisis dampak dari berbagai model penggunaan lahan terhadap pertumbuhan layanan ekosistem dengan pendapatan rumah tangga perdesaan. Hasil penelitian ini menunjukkan adanya variasi yang signifikan dalam layanan ekosistem dan pendapatan rumah tangga yang dihasilkan dari implementasi empat model pengembangan yang berbeda-beda. Satu-satunya desa ditemukan memiliki layanan ekowisata dan 
pendapatan rumah tangga tertinggi, namun di sisi lain ada desa perlindungan ekologis yang memiliki pendapatan lebih rendah. Temuan ini menunjukkan bahwa model pengembangan yang tepat dapat membuat pertumbuhan bersama yang harmonis dari layanan ekosistem dan pendapatan rumah tangga perdesaan. Penulis berpendapat bahwa metode yang digunakan dalam penelitian ini dapat membantu meningkatkan manajemen perdesaan di Cina maupun di tempat lain (K. Zhang et al., 2020).

Untuk mengatasi permasalahan urbanisasi dan homogenisasi lanskap dalam desain desa-desa Cina dalam konteks integrasi perkotaan-perdesaan maka melalui hasil penelitian ini menunjukkan bahwa setelah sistem evaluasi AVC (Attraction-ValidityCapacity) untuk daerah khusus warisan budaya yang mendalam dari Desa Dang disimpulkan bahwa Desa Dang memiliki lingkungan budaya yang baik dan latar belakang yang mendalam. Dilihat dari skor AVC komprehensif lanskap desa Dang yang berjumlah 0.3121 dan skor komprehensif daya tarik, vitalitas, serta kapasitas sebesar $0.3055,0.2985$ dan 0.3381 per masing-masing singkatnya, ia tidak memiliki langkah-langkah perencanaan yang tertib serta pembangunan yang wajar. Akibatnya adalah menghilangnya budaya regional secara unik dan bertahap. Akhirnya dikombinasikan dengan hasil evaluasi dan analisis AVC (Attraction-Validity- Capacity) untuk saran perencanaan konstruksi lanjutan Desa Dang yang dikemukakan dan diterapkan pada penelitian pengajaran praktis. Hasilnya kemudian dapat memberikan referensi untuk mempelajari berbagai ekspresi (Wang, 2021).

Pesatnya perkembangan negara-negara berkembang menyebabkan perencanaan konvensional dan industrialisasi yang tidak masuk akal memunculkan adanya ketidakstabilan di daerah perdesaan. Terutama pada sistem perdesaan yang berbasis sumber daya dan lingkungan yang saat ini mulai mendapatkan perhatian secara luas. Berdasarkan teori analisis, artikel ini membangun evaluasi nilai tambah lingkungan perdesaan dengan sumber daya, pengembangan, ruang, dan perlindungan lingkungan sebagai lapisan faktor termasuk pada 18 sub indikator. Menurut hasil analisis dalam artikel ini lebih mengedepankan pada pendapatan pembangunan dari empat aspek: sumber daya, industri, lingkungan dan investasi pemerintah. Dengan menggunakan metode membangun sistem analisis kuantitatif evaluasi nilai tambah lingkungan perdesaan akan memiliki nilai teoritis dan praktis tertentu dalam panduan serta evaluasi perencanaan perdesaan (Wan et al., 2021).

Mengentaskan kemiskinan, mengurangi ketimpangan, dan mencapai kemakmuran serta kesejahteraan ekonomi merupakan tantangan global. Maka dari itu untuk mewujudkan tantangan tersebut proyek arsitektur untuk Desa Cerdas dapat berkontribusi untuk dijadikan solusi yang efektif dalam membahas skala serta penyesuaian. Untuk mencapai kerangka Desa Cerdas maka dalam artikel ini mengambil pendekatan endogen. Pendekatan ini lebih menekankan pembelajaran yang kemudian menciptakan efek kataliptik untuk skala. Dalam hal ini pembelajaran merupakan komponen penting baik bagi para peneliti maupun bagi anggota masyarakat. Selanjutnya pendekatan ini berlangsung selama empat fase yaitu dimulai dengan penemuan, perencanaan, resourcing, dan pelaksanaan. Dalam artikel ini penulis menempatkan fase penemuan untuk fondasi dalam mengembangkan kerangka kerja dari desa pintar yang dapat diskalakan. Fase penemuan adalah proses dimana penelitian di masyarakat belajar tentang dirinya sendiri dan para peneliti belajar tentang faktor-faktor yang mendasari pengembangan desa cerdas, sehingga dengan fase ini akan membantu mengkalibrasi desa untuk pengembangan desa di masa depan (Murty \& Shankar, 2020).

Pengelolaan dan pemanfaatan Alokasi Dana Desa dalam proses pembangunan desa di Desa Petak Kaja, Gianyar Bali dalam artikel ini lebih dikhususkan pada proses pembangunan dan pemberdayaan di Desa Petak Raja. Alokasi Dana Desa ini lebih bertolak ukur pada prinsip akuntabilitas, transparansi, partisipatif dan responsif yang bertujuan untuk mewujudkan 
penyelenggaraan pemerintahan yang baik di tingkat pemerintahan desa. Berdasarkan prinsip-prinsip demikian hasil penelitian pada artikel ini menunjukkan bahwa tahap perencanaan pembangunan desa telah diterapkan dengan prinsip akuntabilitas yang didukung oleh prinsip transparansi dan partisipasi. Selanjutnya pada tahap implementasi telah menerapkan prinsip transparansi dan akuntabilitas. Melalui prinsipprinsip tersebut alokasi dana desa memberikan dampak yang positif bagi masyarakat Desa Petak Kaja, Gianyar Bali dengan pembangunan yang dilakukan sesuai dengan program desa (Kepramareni et al., 2020).

Dalam beberapa tahun terakhir, transformasi terjadi pada desa-desa di Cina dengan mode perkotaan. Mode perkotaan ini ada setelah pariwisata berkembang pesat di desa tersebut, sehingga banyak dari desa dan kota yang mulai mendefinisikan wilayah mereka sebagai wilayah yang berorientasi pada pariwisata perdesaan. Transformasi tersebut telah menjadikan pertumbuhan perekonomian yang positif bagi Cina dan berdampak pada banyak sekali desa dan kota yang di segani oleh beberapa pihak. Selain itu taktik pemanfaatan ruang yang aktif dan sehat, penciptaan mode produksi perdesaan yang sehat, pengintegrasian ruang plural, dan peningkatan fasilitas umum desa diusulkan untuk memberikan pembaharuan dan renovasi ruang publik desa dalam hal sejarah dan kebudayaan. Hal tersebut diselenggarakan dalam rangka menjaga dan melindungi aset warisan kebudayaan desa di tengah perkembangan zaman pada saat ini (C.Li, 2020).

Perencanaan untuk pembangunan desa telah menekankan pada konstruksi dan kebijakan yang dipimpin pemerintah. Berdasarkan pada artikel ini perencanaan pembangunan perdesaan perlu dikoordinasikan dengan pengembangan kawasan perdesaan yang terencana dan multifungsi secara keseluruhan. Melalui pendekatan historis interpretatif yang melibatkan analisis kebijakan perencanaan hasil dari penelitian pada jurnal ini menunjukkan bahwa pemerintah mengambil peran utama dalam identifikasi sumber daya dan kapitalisasi secara sementara dengan perusahaan yang mengambil peran utama dalam hal mengatur finansial pada perencanaan pembangunan desa. Dalam hal ini finansial yang diatur oleh pemerintah dan perusahaan digunakan untuk penggunaan lahan multifungsi dalam hal kebangkitan perdesaan dalam perencanaan desa. Dengan adanya penggunaan lahan tersebut dapat memangku berbagai kepentingan termasuk kepentingan pemerintah, perusahaan, dan penduduk desa (W.Li et al., 2021).

Akibat dari pembangunan kembali perdesaan yang pesat di Cina menimbulkan permasalahan yang berulang seperti kurangnya pemahaman masyarakat dalam pemilihan karakteristik spasial yang tidak memadai, karakteristik spasial tersebut cenderung melekat pada permukiman tradisional. Untuk mengatasi permasalahan tersebut dalam artikel ini potensi pengembangan penggunaan lahan yang merupakan simulasi pemilihan ruang hidup untuk masyarakat lebih dioptimalkan sesuai dengan aturan tata ruang yang sesuai dengan lahan tersebut. Hasil penelitian pada artikel ini menunjukkan bahwa dengan menggunakan fitur pengenalan spasial dan regresi menghasilkan karakteristik spasial yang memiliki keunggulan untuk mengatasi permasalahan masyarakat dalam hal pemilihan karakteristik spasial (Yang $\& \mathrm{Pu}, 2020)$.

Perubahan penggunaan lahan di Kabupaten Pandaan menunjukkan bahwa memiliki urutan tertinggi keempat di Provinsi Jawa Timur. Perubahan ini disebabkan oleh pertambahan penduduk yang diakibatkan oleh letak Kecamatan Pandaan yang strategis dimana letak tersebut dilalui oleh jalan penghubung antara Kota Surabaya hingga Kota Malang. Hal tersebut mengakibatkan pesatnya perkembangan lahan yang terbangun sehingga muncul inkonsistensi pada pengembangan lahan eksisting sebagaimana yang diatur pada dokumen perencanaan tata ruang. Hasil penelitian pada artikel ini menyatakan bahwa perubahan penggunaan lahan yang paling banyak terjadi dilakukan pada desa atau kelurahan yang dilalui oleh jalan utama antar 
kota, yang kemudian muncul adanya kepadatan pemukiman penduduk di sekitar jalan tersebut. Di sisi lain hasil prediksi menunjukkan bahwa pemukiman meningkat sebanyak $13.62 \%$ dan industri meningkat menjadi 20.7\% (Prayitno et al., 2020).

Selama dua dekade terakhir pembebasan lahan untuk urbanisasi menyebabkan hilangnya banyak lahan pertanian yang terdapat di wilayah pinggiran Hanoi, Vietnam. Hasil penelitian pada studi ini menemukan bahwa terjadi transisi mata pencaharian komunitas yang terjadi sejak dini. Hal tersebut membantu sebagian pekerja lokal untuk bersiap pindah dari pertanian ketika keadaan urbanisasi semakin meningkat dan muncul kebijakan pembebasan lahan yang akan diterapkan. Dengan demikian mereka mampu beradaptasi tanpa mengalami kesulitan besar ketika mengubah mata pencaharian menjadi lebih baik dengan hilangnya lahan pertanian. Namun, ada beberapa kendala dalam transisi awal yang populer pada konteks pinggiran Kota Vietnam Utara, dimana kurangnya lapangan pekerjaan dan pendapatan dari pertanian pada saat itu mendorong pekerja lokal untuk pergi keluar desa dengan tujuan untuk mencari peluang baru. Mereka keluar desa secara aktif memanfaatkan perubahan di sekitar mereka untuk mencari mata pencaharian baru guna menghasilkan pendapatan yang lebih tinggi (Nguyen \& Kim, 2020).

Kebijakan Presiden Indonesia dalam hal pembangunan nasional adalah dimulai dari pelaksanaan pembangunan di daerah desa tertinggal. Pelaksanaan pembangunan tersebut dilakukan dengan cara pembangunan desa secara merata. Dalam rangka mengoptimalkan arah pembangunan, pemerintah pusat mengalokasikan dana yang cukup besar untuk pembangunan desa tertinggal kepada seluruh desa di Indonesia. Selain itu pemerintah pusat juga memberikan kewenangan kepada setiap desa di seluruh Indonesia untuk merencanakan pembangunan berbasis pembangunan partisipatif. Dengan berbasis pembangunan partisipatif nampaknya akan sangat ideal dan relevan dengan situasi pada saat ini yang mengutamakan partisipasi masyarakat dalam pembangunan desa. Namun, hasil penelitian menunjukkan bahwa kenyataannya semangat dan arah kebijakan tidak berjalan sesuai harapan dengan ditemui beberapa kendala seperti tumpang tindih aturan yang sulit dipahami, rendahnya kualitas sumber daya manusia yang berakibat membebani pengelolaan keuangan desa, dan perencanaan pembangunan yang tidak terarah secara kompleks (Nyoman Subanda et al., 2020).

Penataan kembali ruang perdesaan dianggap sebagai metode penting untuk mencapai tujuan dari revitalisasi perdesaan di Cina dalam beberapa tahun terakhir. Dengan banyaknya permintaan lahan di wilayah metropolitan struktur ruang di perdesaan telah mengalami perubahan yang signifikan pada restrukturisasi spasial perdesaan. Studi kasus di Desa Qinggangshu Cina menunjukkan bahwa penataan ruang perdesaan lebih dominan didorong oleh pariwisata yang dihasilkan dari kekuatan internal dan eksternal. Sementara konsolidasi tanah disorot dengan berbagai cara untuk memicu restrukturisasi tata ruang perdesaan dan pariwisata perdesaan. Ada beberapa faktor pendorong penataan ruang perdesaan yang digunakan pada setiap tahapan restrukturisasi perdesaan. Dengan demikian pemerintah harus mampu mengadopsi model manajemen bertahap, dan secara sistematis dengan mengerahkan semua kekuatan untuk mewujudkan pembangunan perdesaan yang berkelanjutan di masa depan (Gao \& Cheng, 2020).

Kebijakan keseimbangan memberikan kesempatan yang efektif dalam mengurangi kontradiksi antara penggunaan lahan di perkotaan dan perdesaan, kebijakan ini pada dasarnya memberikan kerangka perencanaan penggunaan lahan yang ketat. Pada artikel ini membahas terkait evolusi kebijakan keseimbangan, dengan mengambil dua kriteria klasifikasi yaitu lokasi pemukiman dan target pemukiman maka dapat dirangkum kembali bagaimana karakteristik implementasi kebijakan keseimbangan pada area pemukiman di perdesaan. Karakteristik ini juga dinilai 
berdasarkan hubungan sosial dan kondisi kehidupan masyarakat perdesaan. Hasil dari penelitian pada artikel ini mengungkapkan bahwa dengan penataan kembali spasial, administrasi, industri, gaya hidup, lingkungan hidup, dan hubungan sosial yang dipindahkan ke berbagai tingkat pada masyarakat perdesaan menunjukkan karakteristik yaitu semakin meningkatnya pemukiman terpusat pada area perdesaan namun di sisi lain pemukiman terpusat ini tidak membawa perubahan substansial dalam vitalitas perdesaan. Tidak adanya perubahan substansial tersebut akan berdampak pada resiko baru rusaknya heterogenitas di area perdesaan dan memunculkan potensi-potensi permasalahan baru di area pemukiman perdesaan (Gao et al., 2021)

Isu yang berkaitan dengan sistem perlindungan dan perencanaan lanskap pada perdesaan berbeda dengan topik tentang transformasi kawasan pertanian. Hal ini disebabkan karena adanya spasialisasi terpisah yang bertujuan untuk mengimplementasikan gagasan-gagasan green deal yang berkelanjutan. Pada artikel ini menganalisis tentang perbandingan beberapa proyek penelitian independen di wilayah Kamionka Wielka (kawasan pertanian) dan Strzelce Wielkie (lanskap perdesaan dan kawasan hijau). Hasil penelitian dalam artikel ini menunjukkan bahwa sistem ini berguna untuk perencanaan perdesaan dan pertanian kedepannya. Dalam pelaksanaannya hal ini akan membantu pemerintah daerah dalam mewujudkan pembangunan kawasan hijau di area perdesaan yang lebih efektif untuk seluruh desa. Selain itu dapat dijadikan sebagai tolak ukur untuk dokumentasi proyek. Kedepannya pemerintah dapat mencapai kerjasama yang lebih baik dalam solusi perencanaan tata ruang yang sesuai (Baster \& Litwin, 2021)

Saat ini Cina sedang menerapkan strategi revitalisasi perdesaan. Revitalisasi ini dimulai dengan revitalisasi lahan pekarangan yang menganggur dan tidak efisien. Hal ini merupakan langkah terpenting untuk revitalisasi perdesaan. Dalam kajian ini memberikan referensi terkait bagaimana pemanfaatan lahan pekarangan desa secara optimal melalui evaluasi kuantitatif komprehensif. Hasil penelitian dalam kajian ini mengungkapkan bahwa rata-rata efisiensi pemanfaatan pekarangan desa masih tergolong rendah, hal ini dibuktikan dengan masih banyaknya proporsi halaman yang menganggur dan tidak digunakan secara efisien. Lahan pekarangan desa yang tidak efisien tersebut disebabkan oleh beberapa faktor seperti industri perdesaan yang menurun, lahan pertanian per kapita terbatas, dan masyarakat lebih dominan memiliki mata pencaharian sebagai petani. Berdasarkan beberapa faktor penyebab tersebut maka dalam hal ini perlu adanya efisiensi pemanfaatan lahan pekarangan dengan cara memindahkan lahan perdesaan, mengklasifikasi dan mengoptimalkan pemanfaatan pekarangan, mengembangkan industri sekunder dan tersier, dan mengevaluasi potensi pengembangan desa. Dengan demikian lahan pekarangan yang tidak dimanfaatkan akan dikelola kembali secara efisien dan maksimal (Liu et al., 2020).

\section{METODOLOGI}

Pada penelitian ini bertujuan untuk mengkaji berbagai artikel ilmiah yang berkaitan dengan Perencanaan Pembangunan dalam menetapkan Perencanaan Pembangunan Infrastruktur Perdesaan yang sebagaimana telah dipublikasikan ke dalam jurnal internasional bereputasi. Selain itu, artikel reviu yang ada dalam kajian ini diarahkan untuk mengkonseptualisasikan pada kajian tentang menetapkan perencanaan pembangunan infrastruktur perdesaan dengan metode Perencanaan Pembangunan, yang kemudian akan dijelaskan melalui beberapa pertanyaan berikut: (1) Bagaimana relasi di antara klasterisasi dalam penetapan perencanaan pembangunan infrastruktur perdesaan? (2) Apa tema yang lebih dominan dalam kajian penetapan perencanaan pembangunan infrastruktur perdesaan? (3) Apa saja topik yang terkait dengan kajian dalam perencanaan pembangunan desa? (4) Jenis pemetaan apa 
yang digunakan ke dalam kajian perencanaan pembangunan infrastruktur perdesaan? (5) Konsep seperti apa yang digunakan dalam kajian perencanaan pembangunan infrastruktur perdesaan?. Melalui beberapa pertanyaan tersebut maka akan dijelaskan berdasarkan topik kajian, kerangka kerja, dan beberapa temuan penelitian sebelumnya yang telah terindeks dalam database Scopus. Artikel yang akan direviu dalam penelitian ini akan melalui beberapa tahapan seperti : (1) Pencarian artikel dan (2) Pemetaan topik.

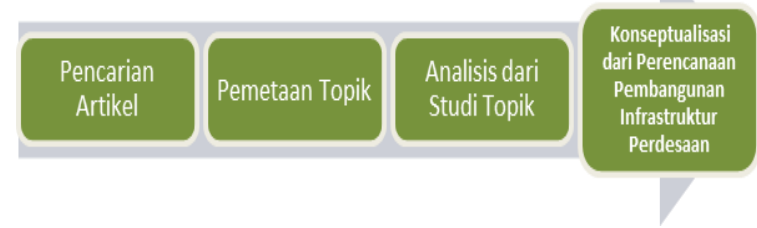

Gambar 1. Proses peninjauan artikel

Pencarian artikel ini dilakukan melalui beberapa tahapan. Pertama, identifikasi apa saja artikel yang akan digunakan. Cara untuk mendapatkan artikel tersebut yaitu dapat dikutip melalui berbagai penerbit dengan menggunakan perangkat lunak berbasis database Scopus. Selanjutnya pada tahap ini mulai memasukkan kata kunci yang sesuai seperti "perencanaan pembangunan infrastruktur perdesaan" dan kemudian menentukan batasan tahun penerbitan. Tahun penerbitan hanya berlaku untuk satu tahun terakhir atau sama halnya dengan tahun 2020 hingga tahun 2021. Pencarian tersebut menghasilkan sebanyak 267 artikel dari 289 artikel yang relevan dengan topik yang akan dibahas.

\section{HASIL DAN PEMBAHASAN}

\section{Keterkaitan dan Pengelompokan Tema dalam Perencanaan Pembangunan Infrastruktur Perdesaan}

Pada bagian ini, konsep akan dijelaskan pada beberapa visualisasi yang berhubungan dengan tema penelitian ini di antaranya diidentifikasi ke dalam 267 artikel. Selanjutnya hasil reviu dengan menggunakan VOSviewer menunjukkan bahwa terdapat 7 Klaster [Tabel 1]. Pada Gambar 1 telah ditunjukkan namanama konsep yang diturunkan dari tampilan data klaster. Selanjutnya kode warna yang digunakan untuk menunjukkan isi dari daftar konsep yang paling dominan dari masingmasing klaster. Tujuannya ialah untuk mengidentifikasi sebanyak mungkin tema yang sering muncul atau yang sering dibahas pada penelitian sebelumnya. Dan kemudian tema tersebut dapat digunakan untuk penelitian selanjutnya. Gambar 1 terlihat bahwa adanya kepadatan klaster yang telah dibedakan oleh warna-warna yang berbeda dari setiap klaster.

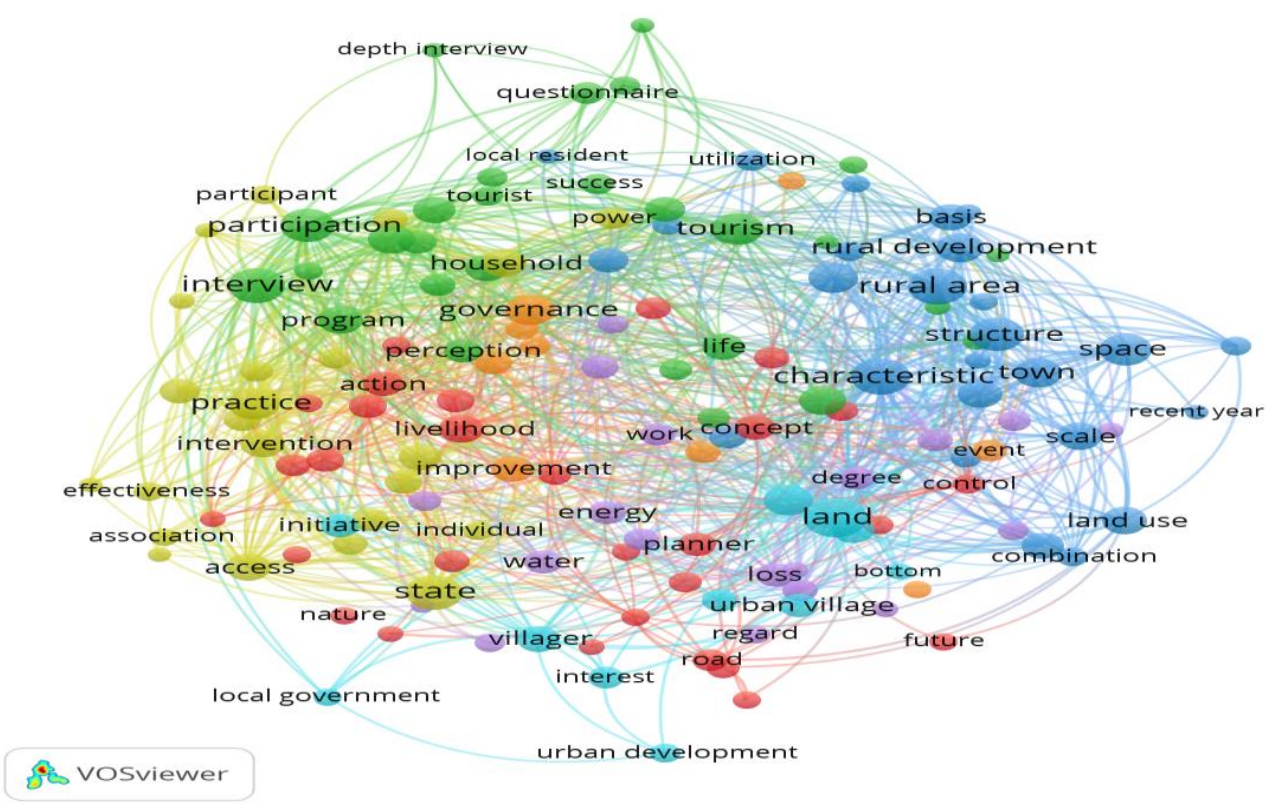

Gambar 2. Hubungan tema yang berkaitan dengan perencanaan pembangunan infrastruktur perdesaan 
Identifikasi dalam bentuk pemetaan pada Gambar 1 dapat membantu peneliti selanjutnya untuk melakukan penelitian baru di mulai dari awal. Ketika mereka telah menemukan topik yang menarik dalam bidang tertentu dan tentunya topik tersebut memiliki kesamaan dengan tema mereka, maka mereka dapat membaca artikel yang memiliki keterkaitan dengan topik yang akan dibahas melalui bantuan studi ini. Pada Klaster 1, konsep yang terkait adalah komunitas lokal, perencanaan, perencanaan tata ruang. Selanjutnya adalah Klaster 2, konsep yang terkait adalah pembangunan desa. Pada Klaster 3, berkaitan dengan konsep daerah perdesaan, pembangunan perdesaan, revitalisasi perdesaan. Kemudian adalah Klaster 4 yang berkaitan yakni efektivitas pembangunan perdesaan, selanjutnya pada Klaster 5 pemukiman perdesaan, dan pembangunan perdesaan berkelanjutan Pada Klaster 6 ada desa perkotaan. Terakhir pada Klaster 7 ada penduduk desa.

Tabel 1. Pengelompokan tema tentang perencanaan pembangunan infrastruktur perdesaan

\begin{tabular}{|c|c|c|}
\hline Klaster & Concept Name & Total \\
\hline Klaster 1 & $\begin{array}{l}\text { komunitas lokal, } \\
\text { perencanaan, } \\
\text { perencanaan tata } \\
\text { ruang. }\end{array}$ & 29 \\
\hline Klaster 2 & pembangunan desa & 28 \\
\hline Klaster 3 & $\begin{array}{l}\text { konsep daerah } \\
\text { perdesaan, } \\
\text { pembangunan } \\
\text { perdesaan, revitalisasi } \\
\text { perdesaan. }\end{array}$ & 26 \\
\hline Klaster 4 & $\begin{array}{l}\text { efektivitas } \\
\text { pembangunan } \\
\text { perdesaan. }\end{array}$ & 23 \\
\hline Klaster 5 & $\begin{array}{l}\text { pemukiman } \\
\text { perdesaan, dan } \\
\text { pembangunan } \\
\text { perdesaan } \\
\text { berkelanjutan }\end{array}$ & 19 \\
\hline Klaster 6 & desa perkotaan. & 11 \\
\hline Klaster 7 & penduduk desa. & 9 \\
\hline
\end{tabular}

Untuk Klaster 1 berkaitan dengan kerja sama perencanaan tata ruang pada tingkat desa di antara pemerintah dengan beberapa pihak yang berkaitan dengan perencanaan tata ruang. Selain itu, kerja sama ini juga dilakukan dengan komunitas lokal desa seperti masyarakat desa itu sendiri. Maka artikel yang relevan dengan Klaster 1 yaitu seperti yang ditulis oleh (Thuesen et al., 2021) dengan judul artikel "Coordination of village plans and municipal rural and health policies-Can low-hanging fruit be picked?" yang dimana pada jurnal ini dikatakan bahwa meskipun perencanaan pembangunan desa bekerja sama dengan masyarakat lokal desa, tetap ada tindakan inovatif terhadap integrasi pada tingkat desa. Selain itu pemerintah dengan pihak-pihak yang bekerja sama dalam pembangunan desa juga perlu memperhatikan keragaman desa, hambatan serta strategi untuk mewujudkan pembangunan desa yang ideal.

Selain artikel di atas ada juga artikel lain yang berkaitan dengan Klaster 1 yang telah dijelaskan oleh penulis (Wikantiyoso et al., 2021) pada artikel terpublikasi dengan judul "Development of Sustainable Community-Based Tourism in Kampong Grangsil, Jambangan Village, Dampit District, Malang Regency" pada artikel ini menjelaskan tentang partisipasi masyarakat dalam pembangunan desa yang mana pembangunan berbasis masyarakat kini telah menjadi kebijakan yang telah ditetapkan oleh pemerintah. Kebijakan tersebut dibuat karena dengan melalui partisipasi masyarakat dapat menghasilkan keputusan, perencanaan, dan desain pembangunan yang berdasarkan pada kebutuhan prioritas serta keterjangkauan. Dengan begitu ke depannya akan menghasilkan pembangunan dan program pada desa yang lebih baik dan realistis.

Pada Klaster 2, topik yang paling dominan yaitu terkait transformasi pembangunan, topik ini memiliki keterkaitan pada artikel yang ditulis oleh (X. Zhang \& Z . Zhang, 2021) dengan judul "How do smart villages become a way to achieve sustainable development in rural areas? Smart village planning and practices in China" pada saat ini 
transformasi pembangunan desa diwujudkan melalui strategi pembangunan Smart Villages. Dalam artikel ini menjelaskan bahwa Smart Villages merupakan model pembangunan desa cerdas yang mengandalkan pemanfaatan teknologi informasi dan komunikasi (TIK) sebagai solusi untuk membangun desa yang lebih berkelanjutan. Selain itu hasil dari penelitian dalam artikel ini juga menemukan bahwa pembangunan dan pengembangan desa pintar menggunakan TIK merupakan pilihan yang tepat pada saat ini terutama untuk transformasi pembangunan desa dari desa tradisional ke modern.

Klaster ke 3 yaitu memiliki topik yang dominan dalam bidang penggunaan lahan. Dalam hal ini artikel yang berkaitan dengan klaster ini adalah artikel yang telah ditulis oleh (Moon et al., 2020) dengan judul "Importance of Government roles for market expansion of eco-village development research: Case study in the city of Suwon, South Korea." Pada artikel ini lebih membahas proyek perwujudan lahan perumahan yang ramah lingkungan. Dengan artian bahwa pemerintah sudah seharusnya berupaya aktif dalam menyiapkan dan membangun metode serta produk konstruksi yang ramah lingkungan jika ingin membuat kebijakan penggunaan lahan yang ramah lingkungan. Penggunaan lahan yang ramah lingkungan dalam pembangunan sangat efektif digunakan untuk menentukan rencana ruang eksternal yang mencakup penggunaan lahan ramah lingkungan di dalamnya.

Selanjutnya adalah Klaster ke 4, pada klaster ini topik yang dominan adalah tentang efektivitas. Topik efektivitas berkaitan dengan artikel yang ditulis oleh (He et al., 2020) dengan judul "Selecting Rural Development Paths Based on Village Multifunction: A Case of Jinjiang City, China" membahas tentang pembangunan desa yang memilih jalur pengembangan multifungsi perdesaan yang cenderung tidak efektif. Hal ini dapat dilihat dari hasil penelitian yang ditunjukkan dalam artikel ini seperti beberapa fungsi perdesaan yang tidak merata, produksi non-agricultural tidak sepenuhnya dikelola dengan baik, dan korelasi antara pembangunan desa dengan fungsinya tidak sesuai dan kurang merata. Maka dari itu dapat disimpulkan bahwasanya ketika melakukan sebuah perencanaan dan pembangunan di desa sudah seharusnya membuat sebuah kebijakan yang mana kebijakan tersebut nantinya akan berfungsi sebagai panduan ilmiah untuk memulai pembangunan desa.

Kemudian pada Klaster 5 topik yang dominan yaitu tentang pemukiman desa. Keterkaitan topik tersebut berkaitan dengan artikel yang ditulis oleh (T. Zhang et al., 2020) dengan judul "Research on regional system planning method of rural habitat in gully regions of the loess plateau, under the background of rural vitalization strategy in China" pada saat ini, desa dinilai dapat dijadikan sebagai lingkungan pemukiman di masa depan maka dari itu demi berkembangnya pemukiman desa yang baik daya dukung ekologis dari lingkungan desa sekitar tidak hanya di dalam desa namun juga di luar desa. Hal ini sangat berpengaruh pada arah pembangunan desa-desa dan perencanaannya. Selain itu penentuan wilayah mana yang tepat untuk diintegrasikan dengan desa adalah hal yang sangat penting, karena dengan begitu desa dapat dinilai dan dijadikan sebagai lingkungan pemukiman masa depan yang sebenarnya.

Klaster 6 topik yang dominan adalah tentang urban village, topik ini berkaitan dengan artikel terpublish yang ditulis oleh (K. Zhang et al., 2020) yang berjudul "Development Models Matter To The Mutual Growth Of Ecosystem Services And Household Incomes In Developing Rural Neighborhoods" membahas tentang hubungan antara pembangunan desa pada kasus urban village dengan pendapatan masing-masing penduduk. Hasil penelitian dari artikel ini adalah banyak variasi yang penting untuk pembangunan desa pada kasus urban village melalui layanan ekosistem yang dimanfaatkan masyarakat desa untuk menambah pendapat dalam sehari-hari. Dengan demikian pendapatan desa pun ikut meningkat karena adanya pemanfaatan ekosistem yang efektif. 
Adapun artikel lain yang membahas tentang urban village adalah artikel yang ditulis oleh (Wang et al., 2021) dengan judul "The practice teaching of regional cultural expression in rural landscape planning and design under the background of urban-rural integration" berkaitan dengan urban village, pembangunan desa perlu adanya pelestarian budaya terutama pengadaan daerah khusus untuk warisan budaya yang ada di dalam desa. Dengan begitu budaya regional yang ada di dalam desa itu tetap bertahan dengan karakteristiknya yang unik.

Klaster terakhir yaitu klaster 7, memiliki topik yang dominan yaitu di bidang Governance. Dalam hal ini telah dibahas pada artikel yang telah diteliti oleh (Wan et al., 2021) dengan judul "Construction And Case Study Of Rural Environmental Value-Added Evaluation System Based On Emergy Theory" dan artikel lain yang ditulis oleh (Murty et al., 2020) yang berjudul "Towards a scalable architecture for smart villages: The discovery phase". Kedua artikel ini sama-sama membahas tentang governance. Hubungan antara governance dengan perencanaan pembangunan desa adalah bagaimana pemerintah nantinya akan membangun Desa Cerdas dengan mengentaskan kemiskinan dan mencapai kemakmuran serta kesejahteraan perekonomian penduduk desa. Kunci dari hal tersebut adalah adanya penyeimbangan di antara sektor industri dengan pemanfaatan sumber daya lokal desa. Terutama pada sistem perdesaan yang memiliki sumber daya dan lingkungan yang melimpah, hal ini perlu menjadi perhatian secara luas. Selain itu dengan adanya kebijakan terkait pemanfaatan sumber daya lokal yang demikian maka akan memberikan nilai tambah terhadap lingkungan perdesaan seperti pengembangan ruang dan perlindungan lingkungan.

\section{Tema Dominan pada Studi Perencanaan Pembangunan Infrastruktur Perdesaan}

Dalam penelusuran topik pembahasan yang terdahulu maka ditemukan beberapa kata yang dominan dengan tema Rural Infrastructure Development Planning, seperti:

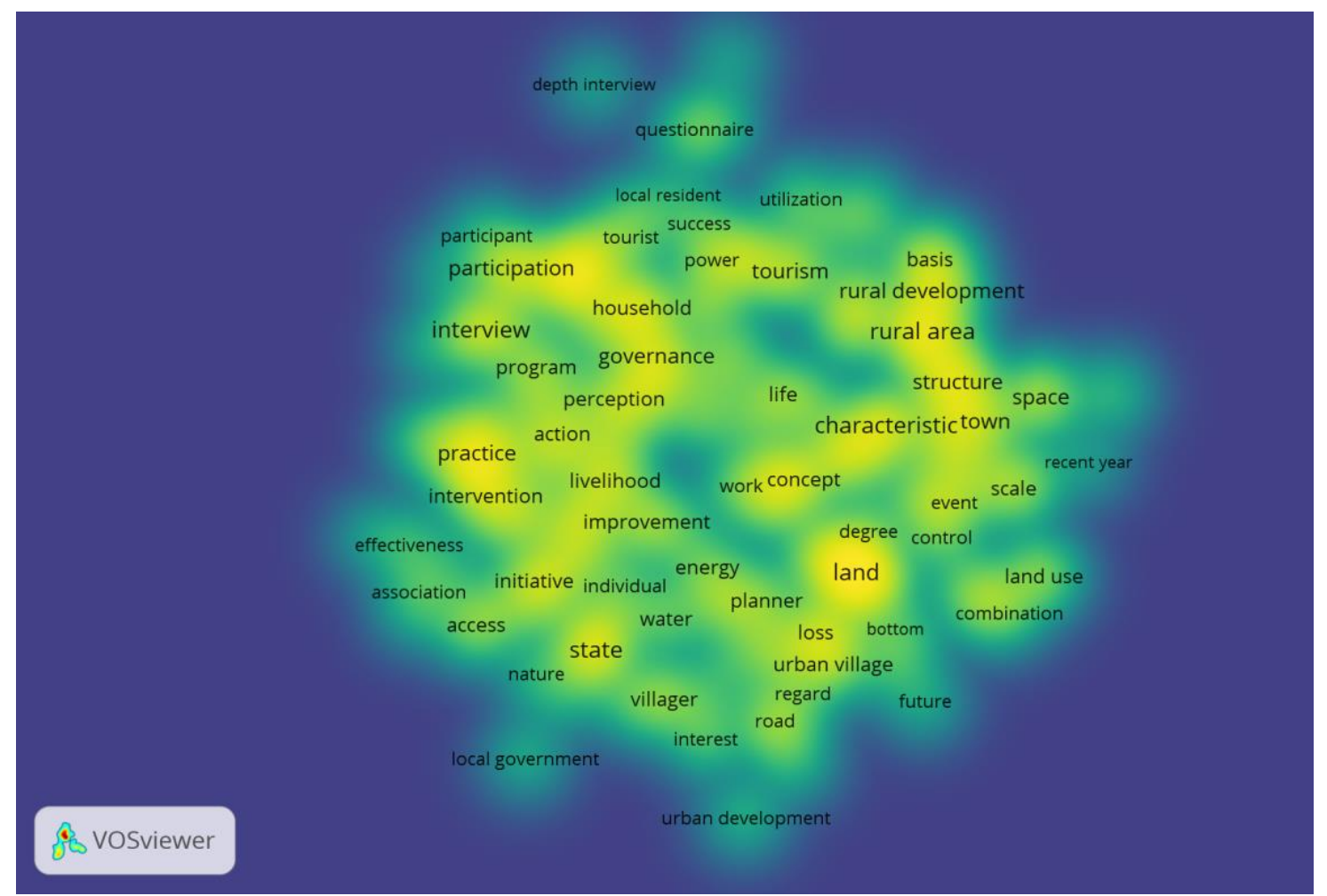

Gambar 3. Konsep dominan tentang perencanaan pembangunan infrastruktur perdesaan dilihat dari Density Visualization 
Dalam Gambar 3 terlihat jelas bahwa konsep yang lebih dominan yaitu ditandai dengan ketebalan warna yang sangat menonjol. Hasil tersebut merupakan tema-tema dominan yang dibahas pada penelitian terdahulu dan berkaitan dengan tema Perencanaan Pembangunan Infrastruktur Perdesaan. Kemudian terdapat konsep (1) Rural Area (2) Land (3) Rural Development. Konsep dari Rural Area dan Land memang mendominasi karena lebih sering digunakan oleh peneliti dalam artikel yang mereka tulis dan kemudian terpublish sesuai dengan tema yang akan dibahas pada penelitian selanjutnya. Sedangkan untuk konsep yang lain merupakan konsep pendukung atau dapat dikatakan konsep yang memiliki pembahasan yang sama, sehingga mendukung konsep dominan yang ada dan begitu juga sebaliknya.

\section{Penulis Dominan pada Studi Perencanaan Pembangunan Infrastruktur Perdesaan}

Author dan penulis memiliki makna yang berbeda-beda, dalam artian author memiliki karya yang sifatnya lebih kepada mengeluarkan ide-ide yang telah ada dan karyanya bersifat spesifik serta tertutup dari opini publik. Sedangkan penulis merupakan seorang yang mempekerjakan dirinya untuk berkarya di dalam bidang yang jumlahnya lebih dari satu spesifikasi. Pada Gambar 3 menunjukkan kumpulan dari beberapa author yang menulis artikel terkait dengan tema Rural Infrastructure Development Planning. Dalam aplikasi Vosviewer, author yang dominan akan muncul dengan ditandai adanya ketebalan warna yang menunjukkan nama author dengan warna yang tebal adalah author yang dominan dengan mempunyai artikel yang berkaitan dengan tema perencanaan pembangunan desa ini.

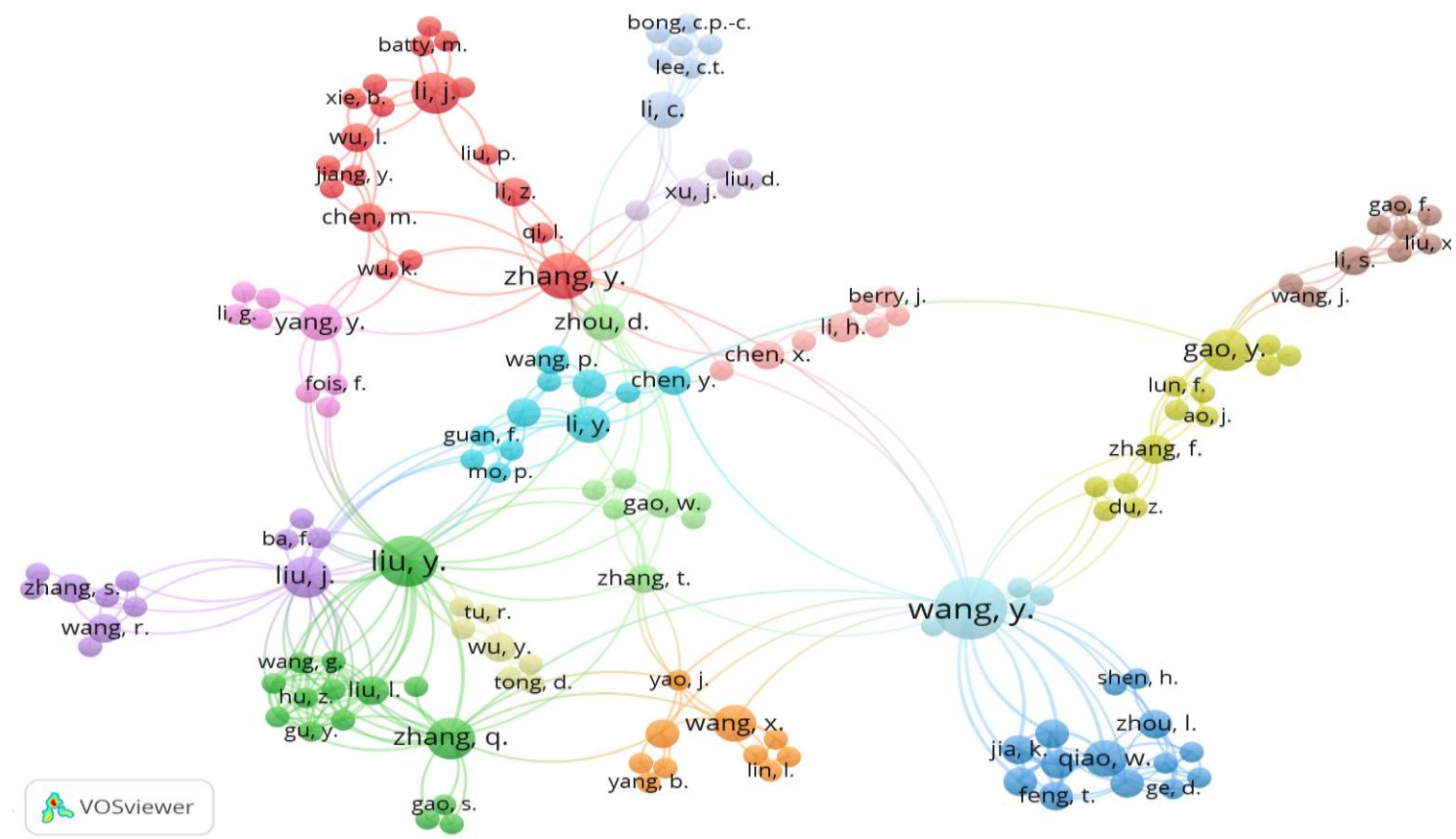

Gambar 4. Pemetaan data Author dengan model Network Visualization

Pada gambar 4 terlihat bahwa author yang dominan adalah wang, y. zang, y dan liu, y. Dengan topik yang berbeda namun masih memiliki keterkaitan pembahasan mengenai perencanaan pembangunan desa. Author disini menjelaskan terkait topik yang akan diambil oleh penulis yaitu perencanaan pembangunan perdesaan dengan kaitannya pembangunan perkotaan. Untuk itu penulis mereviu beberapa artikel yang mendukung topik yang akan dijadikan sebagai judul artikel baru. Kemudian dalam gambar ini, beberapa author tidak sendiri melainkan juga terdiri dari beberapa orang penulis yang menulis mengenai topik yang dibahas ke dalam artikel yang berkaitan dengan perencanaan kawasan perdesaan. 


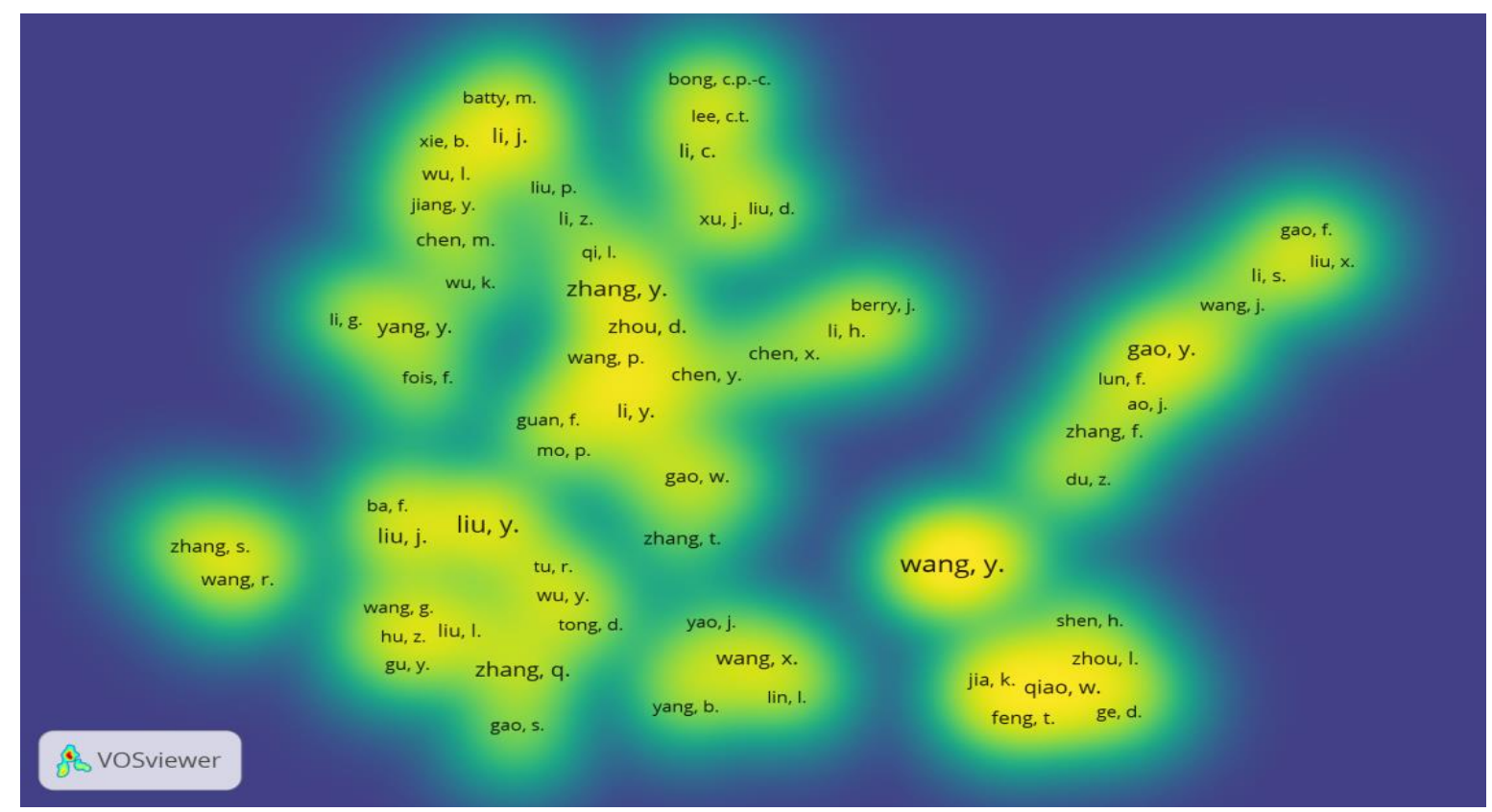

Gambar 5. Pemetaan data Penulis dengan mode Density Visualization

Pada pemetaan data author dengan mode Density Visualization, terlihat beberapa author yang diklasifikasikan berdasarkan beberapa klaster. Dapat dilihat dari jumlah klaster author yang muncul, maka author artikel yang sesuai dengan tema perencanaan pembangunan desa ini berjumlah sebanyak 15 klaster. Klaster author tersebut dominan terletak pada author wang,y yang mempunyai jaring-jaring klaster menyebar dan terikat dengan author-author lainnya. Dengan demikian hal ini menandakan apa yang ditulis oleh author wang,y relevan dengan author-author lainnya tentang tema perencanaan pembangunan desa. Penjelasan terkait klasifikasi Klaster berdasarkan author terdapat dalam Tabel 2.

Tabel 2. Pengelompokan Author dalam studi Rural Infrastructure Development Planning

\begin{tabular}{llc}
\hline \multicolumn{1}{c}{ Klaster } & \multicolumn{1}{c}{ Nama Author } & Total \\
\hline Klaster 1 & batty, m. chen, m. \\
& hou, t. huang, b. \\
& jiang, y. li, j. li, z. \\
& lui, p. ma, r. \\
& mohabir, n. qi, l. tan, \\
& x. wu, k. wu, l. xiao, \\
& x. xie, b. xue, b. yu, \\
& p. zhang, y. \\
\hline Klaster 2 & gao, s. gu, y. hong, \\
& c. hu, z. huang, j. \\
& huang, x. lui, l. liu, \\
& m. liu, y. lu, s. lyu, \\
\hline
\end{tabular}

\begin{tabular}{clc}
\hline Klaster & \multicolumn{1}{c}{ Nama Author } & Total \\
\hline & $\begin{array}{l}\text { y. tong, z. wang, g. } \\
\text { zhang, g. zhang, q. }\end{array}$ \\
\hline Klaster 15 & $\begin{array}{l}\text { dong, l. lin, j. wang, } \\
\text { c. wang, y. zhu, e. }\end{array}$ \\
& \\
\hline
\end{tabular}

Dalam pemetaan Author ini, terdiri dari 15 Klaster namun yang mendominasi hanya 3 Klaster saja, kemudian dari 3 Klaster tersebut ada Author yang mendominasi dalam pemetaan data author yang sesuai dengan studi perencanaan pembangunan wilayah perdesaan. Author tersebut, seperti wang, y. zang, y dan liu, y. Ketiga author tersebut dominan dikarenakan pada setiap klaster mereka berada di titik pusat klaster mereka, selain itu ketiga author tersebut lebih banyak yang relevan terkait dengan topik perencanaan pembangunan perdesaan. Sama halnya dengan melihat Gambar 4, terlihat jelas bahwa author dominan yang muncul ditandai dengan ketebalan warna yang dimana menunjukkan bahwa author dengan warna tebal merupakan author yang memiliki keterkaitan dengan topik atau tema dengan author lainnya secara menyeluruh dari klaster satu ke klaster yang lain. Dilihat dari Tabel 2, pada pemetaan author dengan tema perencanaan pembangunan desa terbagi menjadi 15 Klaster. Namun, dari 15 Klaster tersebut hanya 3 klaster saja yang menonjol. Klaster-klaster tersebut memiliki jumlah author 
yang berbeda-beda. Seperti contohnya pada Klaster 1 sebanyak 19 author, Klaster 2 sebanyak 15 author, dan terakhir Klaster 15 sebanyak 5 author.

\section{KESIMPULAN DAN REKOMENDASI}

Perencanaan pembangunan desa merupakan suatu hal yang tidak semata-mata karena adanya sebuah kesempatan melainkan hal tersebut adalah hasil dari penentuanpenentuan pilihan dari beberapa proses kegiatan dan bukan dari hasil yang tidak terencana namun karena adanya perencanaan yang baik. Untuk menyelenggarakan kewenangan tersebut maka Pemerintah Desa perlu menyusun perencanaan desa yang tentunya melibatkan seluruh komponen yang terkait seperti masyarakat desa dan stakeholder. Dengan demikian proses perencanaan yang baik ke depannya akan menghasilkan hasil yang baik dari pelaksanaan program yang pada akhirnya akan menumbuhkan rasa partisipasi masyarakat yang tinggi dalam hal keterlibatan pada pembangunan desa. Dalam proses perencanaan pembangunan infrastruktur perdesaan sangat perlu adanya dukungan dari beberapa stakeholder yang terkait. Selain itu, dalam hal optimalisasi pemanfaatan sumber daya alam desa juga perlu dilakukan. Hal ini dikarenakan dalam bidang infrastruktur yang pertama diutamakan adalah terkait sumber daya alam yang dimiliki oleh desa itu sendiri. Optimalisasi sumber daya alam desa juga perlu diikuti dengan pengembangan sumber daya manusia desa, karena salah satu terwujudnya pembangunan desa yang ideal adalah partisipasi masyarakat desa itu sendiri dalam membantu mewujudkan pembangunan yang ideal. Maka dari itu perlu adanya kerja sama antara pemerintah dengan masyarakat lokal desa, meskipun perencanaan pembangunan desa bekerja sama dengan masyarakat lokal desa, tetap ada tindakan inovatif terhadap integrasi pada tingkat desa. Selain itu pemerintah dengan pihak-pihak yang bekerja sama dalam pembangunan desa juga perlu memperhatikan keragaman desa, hambatan serta strategi untuk mewujudkan pembangunan desa yang ideal.

Kajian dalam penelitian ini membahas tentang perencanaan pembangunan desa yang mencakup ke dalam 7 klaster dan memiliki tiga topik utama. Selain itu terlihat ada 145 konsep dari 267 artikel yang di dapat melalui database Scopus. Hasil reviu menggunakan VOSviewer menunjukkan bahwa terdapat tiga konsep yang dominan dalam Tema Studi Perencanaan Pembangunan Infrastruktur Perdesaan yaitu membahas konsep terkait (1) Rural Area (2) Land dan (3) Rural Development. Makna penting dari studi ini adalah ditemukannya konsep studi perencanaan pembangunan infrastruktur perdesaan. Dengan demikian penelitian ini dapat membantu dalam kerangka konseptual dalam penelitian selanjutnya.

Adapun keterbatasan dalam penelitian ini adalah minimnya sumber jurnal yang dijadikan rujukan penelitian. Sumber jurnal tersebut terkait dengan jurnal yang sesuai dengan judul yang dibahas, sehingga perlu adanya beberapa penemuan hal-hal baru untuk mengungkap dan meneliti permasalahan di dalam proses perencanaan pembangunan desa khususnya dalam bidang infrastruktur. Selain itu sumber jurnal dalam kajian ini hanya bersumber pada data base scopus dan minimnya variabel yang diteliti untuk memperoleh informasi dari beberapa jurnal sehingga menyebabkan tidak memiliki data pembanding dengan sumber jurnal yang lain.

Keterbatasan juga ditemukan dalam hal perbedaan negara yang memiliki pandangan tersendiri terhadap pembangunan wilayah perdesaan. Terutama pembangunan wilayah perdesaan di Indonesia yang memiliki keanekaragaman budaya serta sifat tradisional masyarakatnya. Selain itu, terkait proses perencanaan pembangunan desa masih dapat dikatakan minim sosialisasi dan implementasinya. Hal tersebut dikarenakan masih banyak negara yang tidak memiliki aturan yang mengikat mengenai pelaksanaan dari perencanaan pembangunan desa. 
Untuk para penulis yang mengangkat topik ini, kedepannya dapat melakukan pemetaan terlebih dahulu dalam hal menentukan topik-topik yang berkaitan dengan judul yang diangkat. Pemetaan topik dapat dilakukan dengan cara melakukan pengalihan hal-hal baru pada artikel yang sesuai dengan judul sehingga dapat mengasah pemahaman serta pokok pikiran yang akan ditulis dan dikembangkan oleh penulis, serta dapat digunakan dalam pengembangan pendapat ilmiah dan penguatan argumentasi dalam penulisan artikel. Selanjutnya adalah kesesuaian di antara topik dengan judul juga harus diperhatikan dengan baik dalam melakukan reviu artikel untuk menambah pemahaman dari artikel yang dibaca. Di sisi lain pemetaan topik juga berguna untuk mengurangi kesalahan dan ketidakpahaman mengenai judul yang diangkat oleh penulis. Kemudian untuk penelitian berikutnya penulis perlu menggunakan artikel yang tidak hanya bersumber dari database scopus namun menggunakan database lain seperti google scholar dan lain-lain.

\section{DAFTAR PUSTAKA}

Baster, P., \& Litwin, U. (2021). Polish rural designing system used for the implementation of the ideas of green deal and sustainabilitycomparison of landscape and agricultural areas planning, on the example of Strzelce Wielkie and Kamionka Wielka. Sustainability (Switzerland), 13(2), 1-17. https://doi.org/10.3390/su13020886

Gao, C., \& Cheng, L. (2020). Tourism-driven rural spatial restructuring in the metropolitan fringe: An empirical observation. Land Use Policy, 95. https://doi.org/10.1016/j.landusepol.2020.104 609

Gao, W., de Vries, W. T., \& Zhao, Q. (2021). Understanding rural resettlement paths under the increasing versus decreasing balance land use policy in China. Land Use Policy, 103. https://doi.org/10.1016/j.landusepol.2021.105 325
He, T., Qiao, W., Jia, K., Chai, Y., Hu, Y., Sun, P., Wang, Y., \& Feng, T. (2020). Selecting Rural Development Paths Based on Village Multifunction: A Case of Jingjiang City, China. Complexity, 2020. https://doi.org/10.1155/2020/7590942

Kepramareni, P., Yuliastuti, I. A. N., \& Mariantini, N. L. M. (2020). Village accountability of village fund management in gianyar Bali Indonesia. Journal of Advanced Research in Dynamical and Control Systems, 12(1 Special Issue), 849-855. https://doi.org/10.5373/JARDCS/V12SP1/20 201136

Li, C. (2020). Research on the public space renewal strategy of Chinese Tujia nationality heritage villages based on the healthy rural theory: A case study of Lianghekou village in enshi xuanen county, Hubei province. WIT Transactions on Ecology and the Environment, 241 (11), 145-155. https://doi.org/10.2495/SDP200121

Li, W., Zhang, Z., \& Zhou, Y. (2021). Policy strategies to revive rural land in perimetropolitan towns: Resource identification, capitalization, and financialization. Land, 10(2), 1-18. https://doi.org/10.3390/land10020132

Liu, Y.-Q., Wang, A.-L., Hou, J., Chen, X.-Y., \& Xia, J.-S. (2020). Comprehensive evaluation of rural courtyard utilization efficiency: A case study in Shandong Province, Eastern China. Journal of Mountain Science, 17(9), 2280-2295. https://doi.org/10.1007/s11629019-5824-х

Moon, S.-Y., Jang, D., Kim, H. S., Lee, J.-Y., \& Kim, J. (2020). Importance of government roles for market expansion of eco-village development plan establishment research: Case study in the city of Suwon, South Korea. Sustainability (Switzerland), 12(24), 1-18. https://doi.org/10.3390/su122410293

Murty, V. K., \& Shankar, S. S. (2020). Towards a scalable architecture for smart villages: The discovery phase. Sustainability (Switzerland), 12(18). https://doi.org/10.3390/su12187580

Nguyen, Q., \& Kim, D.-C. (2020). Reconsidering rural land use and livelihood transition under the pressure of urbanization in Vietnam: A case study of Hanoi. Land Use Policy, 99. https://doi.org/10.1016/j.landusepol.2020.104 896 
Nyoman Subanda, I., Istri Agung Maheswari, A. A., Sucitawathi P, I. G. A. A. G. D., \& Dewi, N. L. Y. (2020). Portrait of village administrator in managing financial and development planning. Journal of Advanced Research in Dynamical and Control Systems, 12(7), 202209.

https://doi.org/10.5373/JARDCS/V12I7/2020 2001

Prayitno, G., Sari, N., Hasyim, A. W., \& Nyoman Widhi, S. W. (2020). Land-use prediction in Pandaan District pasuruan regency. International Journal of GEOMATE, 18(65), 64-71.

https://doi.org/10.21660/2020.65.41738

Thuesen, A. A., \& Andersen, P. T. (2021). Coordination of village plans and municipal rural and health policies - Can low-hanging fruit be picked? Sociologia Ruralis, 61(1), 190-211. https://doi.org/10.1111/soru.12325

Wan, A., Tu, R., Yue, W., Liu, Y., \& Wu, Y. (2021). Construction and case study of rural environmental value-added evaluation system based on emergy theory. Environment, Development and Sustainability, 23(3), 4715-4734. https://doi.org/10.1007/s10668020-00729-7

Wang, X. (2021). The practice teaching of regional cultural expression in rural landscape planning and design under the background of urban-rural integration. International Journal of Electrical Engineering Education. https://doi.org/10.1177/0020720920984308

Wikantiyoso, R., Cahyaningsih, D. S., Sulaksono, A. G., Widayati, S., Poerwoningsih, D., \& Triyosoputri, E. (2021). Development of Sustainable Community-Based Tourism in Kampong Grangsil, Jambangan Village, Dampit District, Malang Regency. International Review for Spatial Planning and Sustainable Development, 9(1), 64-77. https://doi.org/10.14246/IRSPSD.9.1_64

Yang, X., \& Pu, F. (2020). Spatial Cognitive Modeling of the Site Selection for Traditional Rural Settlements: A Case Study of Kengzi Village, Southern China. Journal of Urban Planning and Development, 146(4). https://doi.org/10.1061/(ASCE)UP.19435444.0000616
Zhang, K., Sun, X., Jin, Y., Liu, J., Wang, R., \& Zhang, S. (2020). Development models matter to the mutual growth of ecosystem services and household incomes in developing rural neighborhoods. Ecological Indicators, 115. https://doi.org/10.1016/j.ecolind.2020.106363

Zhang, T., Ding, B., Hu, Q., Liu, Y., Zhou, D., Gao, W., \& Fukuda, H. (2020). Research on regional system planning method of rural habitat in gully regions of the loess plateau, under the background of rural vitalization strategy in China. Sustainability (Switzerland), 12(8). https://doi.org/10.3390/SU12083317

Zhang, X., \& Zhang, Z. (2020). How do smart villages become a way to achieve sustainable development in rural areas? Smart village planning and practices in China. Sustainability (Switzerland), 12(24), 1-20. https://doi.org/10.3390/su122410510 